\title{
EVALUATION OF GROWTH PERFORMANCE AND ECONOMIC ANALYSIS OFBROILER CHICKS FED PLANT DIETS SUPPLEMENTED WITH SOME FEED ADDITIVES
}

\author{
M.S. Hassanien; S.A. Ibrahim; A.I. El-Faham and S.A. El-Safty \\ Poultry Production Dep., Fac. of Agric., Ain Shams Univ., Cairo, Egypt.
}

\section{SUMMARY}

\begin{abstract}
$\Delta$ $\mathrm{n}$ experiment was inducted to determine the effects of betaine, enzyme mixture or L-carnetine as feed additives on growth performance, carcass characteristics and economic efficiency of broiler chicks. A total number of 120 one week old Hubbard broiler chicks were classified into 4 equal groups, each was subdivided into 3 replicates with 10 chicks.

The $1^{\text {st }}$ group was fed basal diet without supplementation (control), while the $2^{\text {nd }}\left(\mathrm{T}_{1}\right)$, the $3^{\text {rd }}\left(\mathrm{T}_{2}\right)$, and the $4^{\text {th }}$ groups were fed the basal diets supplemented with betaine, enzyme mixture and L-carnetime at the level of $1000 \mathrm{~g}, 500 \mathrm{~g}$ and $100 \mathrm{~g} / \mathrm{ton}$, respectively. Diets and water were provided ad lib. throughout the experimental period (1-5 weeks of age).

The results indicated that:

1- Body weight gain for the broiler chicks fed basal diets supplemented with enzyme mixture $\left(\mathrm{T}_{2}\right)$ was significantly differences than those fed control diets at 1-3 wks and 4-5 wks of age. However, during the whole experimental period (1-5 wks), chicks fed basal diets + different feed additives $\left(\mathrm{T}_{1}, \mathrm{~T}_{2}\right.$ and $\mathrm{T}_{3}$ ) gave insignificantly higher live body weight gain compared to the fed control diets.

2- Feed conversion ratio (FCR), during whole experimental period, chicks fed $\mathrm{T}_{2}$ diets had significant better FCR (1.54), on contrary groups fed control basal diets or $\mathrm{T}_{1}$ and $\mathrm{T}_{3}$ diets recorded the worst FCR being $1.65,1.63$ and 1.64 , respectively, due to the insignificant increased of feed consumption.

3- Carcass characteristics parameters (dressing, reading to cook and abdominal fat \%) and carcass parts $\%$ (breast, thigh, drumstick and wing \%) showed insignificant figures when chicks fed different dietary treatments.

4- Bone measurements (wet tibia weight, tibia length, tibia width and tibia seedor index) showed insignificant figures when broiler chicks fed different dietary treatments.

5- Blood parameters showed insignificant figures in most parameters. However total protein, globulin and triglyceride have significant difference for dietary treatments.

6- Economic evaluation the best economic efficiency value was demonstrated when broiler chicks fed 500 g/ton enzyme mixture and the value was (20\%) more when compared with broiler chicks fed control diets.
\end{abstract}

Keywords: Betaine, enzyme mixture, L-carnetine broiler and economic efficiency.

\section{INTRODUCTION}

Poultry production in several areas all over the world has become a major sector of the agriculture industries and its improvement is considered one of the main targets of both public and private sector.

Moreover, feeding costs of poultry production is usually considered the most expensive component in poultry diets. Therefore many attempts were made to reduce feeding expenses by using plant protein diets supplemented with synthetic amino acids (Abd El Samee, 2001; Yakout et al., 2004). Recently, supplementing diets with non-nutritional additives severed as an alternative way to improve nutrient utilization (Osman, 2003).

In addition feed additives have beneficial effects on improving poultry performance and playing role in metabolic and physiological processes (Abd El- Fatah and Shourrap, 2012 and Abd El- Fatah, 2013).

Natural commercial products such as enzyme preparations and other products (betaine or L-carnitine) may be used to improve and maximize genetic potential of broilers regarding feed efficiency and weight gain.

Betaine, the trimethyl derivative of the amino acids glycine [(Me) 3-n+-ch2coo-] (Eklund et al., 2005) has gained interest in recent years as potential additive, enhances domestic animal production because of its metabolic functions. Betaine has many major metabolic functions, it acts as a methyl donor (Eklund $e t$ 
al., 2005 and Ratriyanto et al., 2009); it acts as an osmolyte (Garcia et al., 2000) and improves immune response as well as productivity (Wang et al., 2004).

Also, Betaine was effective in improving growth and feed conversion and has a methionine sparing effect in broilers (Garcia et al., 2000) (Waldenstede et al. (1999) reported that dietary Betaine addition improved performance of chicks. Also, Mona Srgal (2013) reported that (ME) can be reduced from the recommended level by $300 \mathrm{kcal} / \mathrm{kg}$ and supplement this diets with Betaine for broiler chicks (Ross strain) reared during the summer period.

During recent years, L-carnitine (B-hydroxy-trimetyl- aminobutyrate), has gained increasing attention as commercially feed additive in poultry nutrition. L-carnitine has beneficial effects on preventing some diseases, strengthening immune system, improving poultry performance and playing rule in metabolic and physiological process (Yalcin et al., 2008) The main physiological role of L-carnitine is to drive short ,medium, and long-chained free fatty acids through cell compartments as acyl-carnitine esters. (Arduini $e t$ al., 1992) Also, providing the body with sufficient supplies of L-carnitine can induce more efficient utilization of dietary energy and protein (Harmeyer, 2002).

Several studies in avian species demonstrated a growth improvement by feeding additional dietary Lcarnitine (Rabies et al., 1997).

Abd El-Fatah (2013) concluded that, supplementary L- carnitine with 200ppm up to 400ppm was adequate for enhancing immunity status and antioxidant systems, consequently the growth performance traits of growing Japanese quails. Research has shown (Kita et al., 2002) that, the improvement in body weight gain caused by dietary L-carnitine supplementation might be partially controlled by the change in plasma insulin - like growth factor -1 concentration.

Currently, multi-enzyme preparations have been used as a feed supplement in diets of different classes of poultry to enhance productive performance and immune responses (Jia et al., 2009). Feeding enzymes to poultry is one of the major nutritional advances in the last 50 years.

Enzymes have been approved for use in poultry feed because they are natural products of fermentation and therefor pose no threat to the animal or the consumer.

Enzymes not only well enable livestock and poultry producers to economically use but well also prove to be environmentally friendly, as they reduce the pollution associated with animal production as well as contributing to improved poultry production (Khattak et al., 2006; Yu and Chung, 2004).

The addition of a commercial of multi-enzyme containing Xylanase, amylase, and protease activities to a plant diet for broiler results in a significant improvement in body weight, body weight gain and feed conversion ratio (Greenwood et al., 2002; Yu and Chang, 2004; Osman et al., 2007 and Perić et al., 2008). In contrast, Sanaa El Nagar (2012) found that, the addition of either enzyme mixture, commercial probiotic or their mixture had slightly increased but didn't reach significance both body weight and body weight gain compared to the control it has been demonstrated that, the supplementation of poultry diets with enzyme frequently exerts beneficial effects. The extent of the benefit depends on a number of factors, such as the nature of the dietary components, whether or not the diets have been processed and whether the appropriate enzyme have been included for the substrates contained in the diets (El-Faham and Manar Ibrahem, 2004).

This study aimed to investigate the effects of supplementing either Betaine, enzyme mixture or Lcarnitine to the plant diets on the growth performance and economic analysis of broiler chickens

\section{MATERIALS AND METHODS}

This study was carried out in the poultry experimental unite, Agriculture Experiment and Research Station at Shalakan, Faculty of Agriculture, Ain Shams University, in order to investigate growth performance, some blood components, carcass characteristics and economic efficiency of broiler chickens fed all - plant protein diets supplemented with either Betaine, enzyme mixture, or L-carnitine as feed additives . Enzymes mixture (Nutrikem dry) contained exogenous enzyme (Xylanase, Cellulase and Betaglucanase) and endogenous enzyme (Alpha amylase and protease); all enzyme inarched on matrix of Lysophosphatydial choline. A total number of one hundred and twenty Hubbard broiler chicks, one week old were randomly divided into 4 equal groups, each was subdivided into 3 replicates with 10 chicks each. Chicks were housed randomly into battery brooders to 4 dietary treatments from 1 to 5 weeks, under similar conditions of management and disease control. As shown in table (1), the experimental diets were based on corn - soy diets and formulated to meet the nutrient requirements of broiler chicks according to NRC (1994).Starter diets were offered from 1 to 3 weeks of age while, grower diets were fed from 4 to 5 weeks of age. 
Four dietary treatment diets including the control without supplementation and three test diets supplemented with either Betaine at $(1000 \mathrm{~g} /$ ton feed), enzyme mixture at $(500 \mathrm{~g} /$ ton feed) and commercial L-carnitine at ( $100 \mathrm{~g} /$ ton feed) at starter and grower period, respectively.

The performance parameters included body weight and feed intake which were determined at the end of starter ( 3 weeks of age) and grower ( 5 weeks of age) period and then body weight gain and feed conversion ratios were calculated. At 5 weeks of age (end of the experiment), three birds from each treatment representing the average body weight of each treatment were slaughtered. After slaughtering and complete bleeding, the birds were scalded and feathers were removed. Carcasses were eviscerated then, feet, head, neck and shanks were removed then the carcasses were weighted. Giblets included liver, heart and gizzard as well as abdominal fat percentage was calculated in relation to live body weight. Carcasses parts \% were evaluated using breast, thigh, drumstick and wing weights and percentages was calculated in relation to carcass weight .

Bone quality measurements were evaluated using wet and dry tibia weight, tibia length and weights and tibia Seedor Index (SI) using the following equation suggested by Seedor et al. (1991). [SI = Tibia dry weight $(\mathrm{g}) /$ tibia length $(\mathrm{cm})]$.

Individual blood samples were collected in dry clean centrifuge tubes from the slaughtered birds and plasma was separated by centrifugation at $3000(\mathrm{rpm})$ for 15 minutes and assigned for subsequent determination. Plasma samples were, stored at $\left(-20^{\circ} \mathrm{c}\right)$ in a deep freezer until the time of chemical determination. Values of total protein, albumin, triglyceride, total cholesterol, low density lipoprotein (LDL) and high density lipoprotein (HDL) were estimated by using commercial diagnosing kits (produced by Bio-diagnostic company, Egypt) the globulin values were obtained by subtracting the values of albumin from the corresponding values of total proteins.

Economic parameters of production including feeding cost (starter and grower diets) income and returns per bird were calculated. Economic efficiency was calculated as net return / total coast (Bayoumi, 1980). Relative economic efficiency $=$ assuming control treatment $100 \%$.

\section{Statistical analysis:}

Data were statistically analyzed according to ANOVA procedures of SAS (SAS Institute, 2002). Means differences were compared using Duncan's Multiple Range Test (Duncan, 1955).

\section{RESULTS AND DISCUSSION}

\section{Productive Performance:}

\section{Initial body weight and body weight gain:}

The initial body weight and body weight gain of broilers as affected by dietary treatments which are illustrated in table (2). It is clear that the initial live body weight of chicks at one week old of age was nearly similar among all the experimental groups and the corresponding values ranged between 122.5 and $131.0 \mathrm{~g}$, the differences were statistically not significant. It is worth to note that the chicks fed enzyme mixture diets (T2) during starting period ( $1-3 \mathrm{wks})$ reflected the lowest significant $(\mathrm{p}<0.05)$ result in body weight gain compared with the other treatments and chicks decreased by $7.17 \%(634.5$ vs $680 \mathrm{~g}$ ) compared with the control group . On the other hand, chicks fed (T2) diets during growing period (4-5 wks) showed the highest increasing in body weight gain being $(7.65 \%)$, compared with the control group $(1400.5 \mathrm{vs} 1301.0 \mathrm{~g})$. In addition, during the hall experimental period (1-5wks), chicks fed basal diets + different feed additives (T1, T2 and T3) gave higher live body weight gain compared to those fed control, basal diet and chicks fed containing basal diet $+\mathrm{L}$. carnitine (T3) $+3.2 \%$ basal diet + enzyme mixture (T2) $+2.7 \%$ or basal diet + Betaine (T1) $+1.2 \%$ supported the highest body weight gain than those fed control basal diet. The corresponding figures were 2045, 2035, 2006 and 1981.5 respectively the differences failed to be insignificant.

\section{Feed consumption and feed conversion:}

The results of feed consumption per bird revealed insignificant difference among the experimental treatments as shown in (table 2). However, there was a great tendency of chicks fed (T2) diets to decreased feed consumption than those fed control basal diet. The decrease in feed consumption was more pronounced during growing period ( $4-5 \mathrm{wks})$ being $-4.4 \%$, while it was only $-3.9 \%$ during the starting period (1-3wks). This may have a pronounced reflection on feed consumption all over the experimental period (1-5wks) - 4\%. The corresponding figures were 3122.5 and $3253 \mathrm{~g}$, respectively and the differences failed to be insignificant compared with those fed control basal diet. On the other hand, it is interesting to state that under the condition of the present study, the chicks fed basal diet + L.carnitne 
(T3) feed consumption per bird was insignificantly increased Compared with those fed control basal diets. The increase in feed consumption was more pronounced during growing period (4-5wks) being $(75 \mathrm{~g})$ $+3.3 \%$, while it was only $(7 \mathrm{~g})+0.7 \%$ during the starting period $(1-3 \mathrm{wks})$ and it was $(82 \mathrm{~g})+2.0 \%$ during all over the experimental period (1-5wks).

The results of feed conversion ratio ( $\mathrm{g}$ feed/ $\mathrm{g}$ gain) revealed insignificant difference among the experimental treatments during starting period (1-3wks) as shown in (table 2). However, during the whole experimental period (1-5wks) chicks feed basal diet + enzyme mixture (T2) had significant better FCR (1.54), on contrary groups fed control basal diets or (T1 and T3) diets recorded the worst FCR being 1.65 , 1.63 and 1.64 respectively, due to the increased of feed consumption during the whole experimental period and differences were significant $(\mathrm{p}<0.05)$.

\section{Carcass characteristics:}

Table (3) shows the effect of Betaine, enzyme mixture or L-carnitine supplementation to control basal diets on carcass characteristics for the chicks slaughtered at the end of (5wks) of age.

Experimental treatments with different feed additives (T1-3) had no significant effect on most studied parameters compared with control. The corresponding values for dressing percentages ranged between 71.15 and $74.89 \%$, while ready to cook percentage ranged between 75.67 and $79.5 \%$. On the other hand, the birds fed control diet gave the lowest figure $1.11 \%$ for gizzard percentage. This may have a pronounced reflection on giblets percentages the corresponding figures were $3.82 \%$ and the differences failed to be significant compared with those fed other experimental diets.

Moreover chicks fed control diets showed the lowest abdominal fat percentage being $1.59 \%$ while; chicks fed (T1-3) had the highest figures being 1.70, 1.69 and 2.15\% respectively. The differences among treatments were not significant.

\section{Carcass parts:}

Table (4) shows the effect of different experimental treatments on carcass parts percentages for slaughtered chicks at the end of ( $5 \mathrm{wks}$ ) age. No significant different in all studied traits were obtained due to experimental treatments, but there was a little increased in breast $\%$ and breast muscle $\%$ by feeding enzyme mixture diets (T2) compared with those that feed control diets ,the corresponding figures were (48.57 and 25.62 vs 47.41 and 24.45 respectively), without any significant differences.

On the other hand, the chicks fed (T2) diets reflected the lowest insignificant thigh and wing \% with those fed control diets, the corresponding figures were (26.05 and 10.45 vs 27.19 and 11.00 respectively).

\section{Tibia measurement:}

Table (5) shows the effect of different experimental treatments on tibia measurements for chicks at the end of (5wks) of age. It was clearly noted that the inclusion different feed additives in chick diets (T1-3) had no significant effect on studied parameters compared with control. The corresponding values for wet tibia weight ranged between 10.72 and $12.37 \mathrm{~g}$. While tibia length ranged between 8.47 and $8.93 \mathrm{~mm}$, tibia seeder index (SI) ranged between 0.62 and 0.69. On the other hand, the chicks fed (T1) Betaine diets gave the lowest figures of $10.72 \mathrm{~g}, 0.58 \mathrm{~mm}$ and 0.62 for wet tibia weight, tibia width and Seedor Index (SI) respectively and the differences were insignificant compared with the other experimental treatments.

\section{Blood parameters:}

The results concerning on the effect of different dietary treatments on some blood parameters are shown in table (8). Although the levels of total protein for birds that fed L-carnitine close to control, but numerical, the levels have higher than control, and that means, L-carnitine improved the protein metabolism. The birds that fed L-carnitine and control have improved immunity and that appeared by the levels of Globulin and Albumin/ Globulin (A/ G). Ratio compared with other treatments and the differences between treatments significantly different $(\mathrm{p}<0.05)$.

Regarding lipid metabolism, the results indicated that the chickens that fed on Betaine and enzymes have the lowest concentrations of triglyceride than other treatments and the differences between treatments significantly different $(\mathrm{p}<0.05)$.

It may be these treatments have some substances and could utilize triglyceride that present in the gastrointestinal tract for their own metabolism thus reducing the amount of triglyceride absorption.

Interestingly, cholesterol concentrations for birds that fed on the Betaine and control have the lowest levels than other treatments $(\mathrm{p}<0.05)$. On the other hand both low density lipoprotein (LDL) and High density lipoprotein (HDL) concentrations have the lowest levels $(\mathrm{p}<0.05)$ for the birds that fed on Betaine than other treatments and control.

That means Betaine supplementation have improvement effect in lipid metabolism and decreased the LDL and that lead to decrease the detritus effect of lipid accumulation in the bird's body and consequently that reflect on human's health.

\section{Economical evaluation:}

Data for economical evaluation are summarized in Table (7). The economical evaluations were calculated according to the input-output, economic efficiency and relative economic efficiency. However, 
the price figures are based on the recent prices of local market for fed ingredients and selling price of live broiler chickens in Shalakan - Qalyubia region, Egypt. The average cost / ton of final experimental diets (starter and grower) (T1-3) relatively increased the cost / ton final diets compared with the control Table (1). This difference could be explained on the basis that feed additives (Betaine, enzyme mixture and Lcarnitine) treatments raised the feed cost as compared to Un-supplemented diets and the corresponding increasing values were $0.9,1.0$ and $0.7 \%$ respectively.

As shown in Table (7), it's interesting to state that under the condition of the present study, the chicks fed basal diets supplemented with Betaine (T1), enzyme mixture (T2) and L-carnitine (T3) supported the calculated economic efficiency percentages of chicks efficiently as the control diet and the corresponding increasing were 4.20 and $6 \%$ respectively.

In this study from 7 to 32 days of growth period, Betaine supplementation in broiler corn - SBM basal diets did not affect the body weight gain, feed consumption and feed conversion ratio. These findings are in agreement with those reported by (Zhan et al., 2006) who demonstrated that Betaine had no significant effect on final weight, feed consumption and feed conversion ratio.

In contrast to these observations there have been other reports demonstrating that positive impact on bird performance of supplementing the diet with Betaine. (Remus, 2002; Remus et al., 2004; Wang et al., 2004; Abd El-Gawad et al., 2005 and Ragab, 2013).

Furthermore, the present study showed that enzyme mixture had a positive effect on broiler performance. These results are in agreement with several reports regarding enzyme addition in broiler corn - SBM basal diets (Kocher et al., 2003; Cowieson et al., 2006; Salah et al., 2005; Kalmendal and Tauson, 2012 and Safaa, 2013), who reported that supplementing corn - SBM based broiler diets with an enzyme product containing Xylanase, amylase and protease improved body weight gain and feed efficiency compared with the un-supplemented diets, but feed intake did not affected. The mode of action of enzyme has been linked to improved starch digestibility, improved protein solubility and digestibility, reduction in the inimical effects of corn andlor soy - derived anti-nutritive factors and modification of the intestinal microbial communities. Moreover, Gracia et al. (2003) demonstrated that amylase was a critical enzyme to improve the nutritional value of corn - basal broiler diets, improving body weight gain and feed conversion ratio by 4 to $9 \%$ compared with an un-supplemented control diet.

On the other hand, similar observation was reported by (Xu et al., 2003 and Cevek and Ceylan, 2005). They found that L-carnitine had no effect on body weight, other authors who studied the effect of Lcarnitine on broiler performance found that L-carnitine had a positive effect on the body weight of chickens at 53 days, but the differences were not significant (Rabie and Szilagyi, 1998).

Also, supplemented L-carnitine to drinking water improved feed conversion during the whole rearing period, reduced mortality and contributed to increases in average body weight. (Michalczuk et al., 2012).

Dressing of broilers in the current trial represented by carcass relative weight, carcass parts percentages and some bone measurements were not affected by the different feed additions (Betaine, mixture enzyme \& L-carnitine). However, gizzard and giblets percentages were increased significantly $(\mathrm{P}<0.05)$. These results are in agreement with Nadeem et al. (2005) who reported that dressing percentage and relative weight of heart and shank at 42 days of age was found to be non- significantly different among all groups. (Supplemented or un-supplemented with non- starch polysaccharide degrading enzymes). The results in the literature are highly variable with some studies noted a significant increase in dressing percentage in broilers given a corn - SBM diets supplemented with commercial enzymes. (Salah et al., 2005; Café et al., 2002 and Safaa (2013).

Also, Barekatain et al. (2013) observed a negative interaction between Xylanase and protease resulting in a reduction in relative weight of gizzard at 21 days of age, but these differences were not noted at 7 days of age.

Other authors who studied the effect of L-carnitine on carcass composition and carcass yield were obtained different results, Celik and Ozturkcan (2003). Celik et al. (2003). and Kidd et al. (2009). They showed that L-carnitine supplementation had no effect on dressing percentage. Also, the addition of Lcarnitine caused a non-significant increase in the proportion of breast and leg muscles Zhang et al. (2010). Different results were reported by Daskirian and Teeter (2001) for broilers, in which dietary Lcarnitine exerted no effect on the proportion of breast muscles.

Improved dressing percentage was reported by Zhang et al. (2010) and Michalczuk et al. (2012) Xu et al. (2003) revealed that supplemental L-carnitine increases the proportion of the breast and thigh muscles in the carcass of broiler chickens. Michalczuk et al. (2012) found that L- carnitine supplemented to the drinking water improved dressing percentage and proportion of leg muscles (males), reduced the proportion of breast muscles (males and females), and decreased carcass fatness (males).

Abd El-Gawad et al. (2005) and Ragab (2013) reported that dietary Betaine supplementation had no significant effect on dressing and slaughter parameters percentages. However, Esteve and Mack (2000) reported that Betaine significantly improved carcass percentage but not carcass and breast weight. 
However, numerical improvements in relative weights of abdominal fat were frequently observed when Betaine, enzyme mixture \& L-carnitine were added compared with that of control group. However, these did not reach a level of statistical significances.

These results agree with the finding of Attia et al. (2005) who reported that abdominal fat increased with Betaine supplement. Similar results were obtained by Buyse et al. (2001), who observed the proportion of abdominal fat to increase in the experimental group (supplemented with L- carnitine) of males and to decrease in females. Opposite results to those in the L-carnitine study were obtained by Wang et al. (2003), who found fat content to decrease in the experimental groups supplemented with Lcarnitine with statistically significant differences.

\section{CONCLUSION}

From the present results, it could be still that supplemented basal diets (starter and grower) with $1 \mathrm{~kg}$ Betaine, $0.5 \mathrm{Kg}$ enzyme mixture or $100 \mathrm{~g} \mathrm{~L}$-carnitine / ton ration would have a positive effect on the cost of production and the economic efficiency of broiler chicks without any adverse effect on productive performance or carcass traits of the broilers comparable to the control.

\section{REFERENCES}

Abd El-Gawad, A.H.; M.M.A. EL-Monairy and A.A. Hemid (2005). Dietary supplementation of betaine as an attempt to alleviate the effects of heat stress on broiler chicks. J. Agric. Sci. Mansoura Univ., 30:3585.

Abdel-Fattah, S.A. (2013).Some immune physiological responses of Japanese quail to dietary L-carnitine supplementation. Egyption J. Nutrition and feeds, 16(1):141-149.

Abd-EL samee, M.O. (2001).Broiler performance as affected by crude protein, lysine and a probiotic. Egypt. poult. Sci., 21(IV):943-962.

Abdel-Fattah, S.A. and M.I. Shourrap (2012). Physiological effects of in ovo L-canitine and embryonic thermal conditioning on per and post hatch development of broiler chicks. $3^{\text {rd }}$ Mediterranean poultry summit and $6^{\text {th }}$ international poultry conference 26-29 March, Alex., Egypt.

Arduini, A.; G. Mancinelli; G.L. Radatti; S. Dottori; F. Molajoni and R.R. Ramsay (1992). Role of carnitine and carnitine palnitoyl transferase as integral components of the pathway for membrane phospholipid fatty acid turnover in intact human erythrocytes. J. Biol. chem., 267:12673-12681.

Attia, Y.A.; R. Hassan; M.H. Shehatta and S.B. Abdel-hady (2005). Growth, carcass quality and serum constituents of slow growing chicks as affected by betaine to diets containing 2.different levels of methionine. Inte. J. Poult. Sci., 4:856-865.

Barekatain, M.R.; C.antipatis, M. Choct and P.A. LJI.(2013).Interaction between protease and xylanase in broiler chicken diets containing sorghum distillers dried grains with solubles .Anim. Feed Sci. Technol., 182:71-81.

Bayoumi, S.B. (1980). Effect of different ration on egg production of breeding hens.M.Se. Thesis, Fac. Agri., Kafr El-Sheikh,Tanta University, Egypt.

Buyse, J.; G.P Janssens; J. Decuypere (2001). The effects of dietary L-carnitine supplementation on the performance, organ weights and circulating hormone and metabolite concentrations of broiler chickens reared under a normal or low temperature schedule. British poultry science, 42:230-241.

Café, M.B.; C.A. Borges; C.A. Fritts and P.W. Waldroup (2002). Avizyme improves performance of broilers fed cornsoybean meal-based diets.J.Appl.poult.Res., 11:29-33.

Celike, L. and O. Ozturkcan (2003). Effects of dietary supplemental L-carnitine and ascorbic acid on performance,carcass composition and plasma L-carnitine concentration of broiler chicks reared under different temperature . Archives of Animal Nutrition, 57:27-38.

Celik, L.; O. Ozturkcan; T.C. Inal; N. Canacankatan and L. Kayrin (2003). Effects of L-carnitine and niacin supplied by drinking water on fattening performance, carcass quality and plasma L-carnitine concentration of broiler chicks. Archives of Animal Nutrition, 57(2):127-136.

Cevik A.F.; N. Ceylan (2005). Effects of dietary L-carnitine supplementation on perfor mance and carcass traits of broiler chickens. $3^{\text {rd }}$ Ulusal hayvan Besleme kongresi , Adana, 391-396.

Cowieso, A.J.; D.N. Singh and O. Adeola (2006). Prediction of ingredient quality and the effect of a combination of xylanase, amylase, protease and phytase in the diets of broiler chicks .1. Growth performance and digestible nutrient intake .Br. Poult, Sci., 47:477- 489. 
Daskirian, M. and R.G. Teeter (2001). Effects of dietary L-carnitine (carniking) supplementation on overall performance and carcass characteristics of seven week old broiler chickens.Oklahoma Agricultural Experiment station, 986pp.

El-Faham, A.I. and Manar, T. Ibrahim (2004). Effect of enzyme supplementation on performance, meat quality and economic evaluation of broiler chicks fed low protein diets. Annals of Agaric., Moshtohor, 42(3):1009-1026.

Eklund, M.; E. Bauer; J. Wamatu and R. Mosenthin (2005).Potential nutritional and physiological functions of betaine. Livestock. Nutrition Research Review, 18:31-48.

Esteve, G.E. and S. Mack (2000). The effect of DL-methionine and betaine on growth performance and carcass characteristics in broilers. Anim. Feed Sci. Technol., 87:85-93.

Gracia, M.I.; M.J. Aranibar; R. Lázaro; P. Medel and G. Gmateos (2003).Alpha-amylase supplementation of broiler diets based on corn. Poult. Sci., 82:436-442.

Gaŕcia, N.M.; G.M. Pesti and R.I. Bakalli (2000).Influence of dietary protein level on the broiler chickens response to methionine and betaine supplements .Poult. Sci., 79:1478-1484.

Greenwood, M.W.; C.A. Fritts and P.W. Waldroup (2002). Utiliztration of Avizyme 1502.In corn-soy meal broiler diets with and without antibiotics .Proceeding of SPSS. Abstract number 25.

Harmeyer, J. (2002).The physiological rol of L-carnitine.Lohman Info., 27:15-21.

Jia W.; B.A. Slominski; H.L. Bruce; G. Blank; G. Crow and O. Jones (2009). Effects of diet type and enzyme addition on growth performance and gut health of broiler chickens during sub clinical clostridium perfringens challenge. Poult. Sci 2009.88:132-140.

Kalmendal, R. and R. Tauson (2012). Effects of a xylanase and protease, individually or in combination and an ionophore coccidiostate on performance, nutrient utilization and intestinal morphology in broiler chickens fed a wheat- soy bean meal-based diet. Poult.Sci., 19:1387-1393.

Khattak, F.M.; T.N. Pasha; Z. Hayat and A. Mahmud (2006).Enzymes in poultry nutrtion. J. Anim. PI.Sci:, 16 (1-2).

Kita, K.; K. Nagao; N. Taneda; Y. Inagaki; K. Hirano; T. Shibata; M. Aman Yaman, M.A. Conlon and J. Okimura (2002). Insulin-like growth factor binding protein -2 gene expression can be regulated by diet manipulation in several tissues of young chickens. J. Nutr., 132:145-151.

Kocher, A.; M. Choct; G. Ross; J. Broz and T.K. Chung (2003). Effects of enzyme combination on AME of corn-SBM based in broilers. J. Appl. Poult. Res., 12:275-283.

Michalczuk, M.; M. lukasiewicz; J. Niemiec; A. Wnuk and N.M. Sosnwska (2012). Anim.Sci., 51:89-99.

Nadeem, M.A.; M.I. Anjum; A.G. Khan and A. Azim (2005). Effect of dietary supplementation of nonstarch polysaccharide degrading enzymes on growth performance of broiler chicks. Pakistan Vet. J., 25(4):183-188.

Osman, A.M.A.; M.A.H. Soliman; H.H. Hassanien and A.A.A. Abd-El-Warth (2007). Evaluation of the growth performance of broiler chicks fed on plant diets supplemented with some feed additives .J. Agric. Sci. Mansoura Univ., 32(1):133-150.

Osman, Mona (2003). The influence of probiotic inclusion on the productive performance of commercial layeŕs. Egypt. Poult. Sci., 23(1):283-297.

Perić, L.; N. Milośević; M. Dukić-Slojčić; S. Bjedov and V. Rodić (2008). Effect of enzymes on performances of broiler chickens. Biotechnol. Anim. Husband., 24(5-6):45-51.

Rabies, M.H.; M. Szilagyi and T. Gippert (1997). Effects of dietary L-carnitine on the performance and egg quality of laying hens from 65-73 weeks of age.Br-J.of.Nutrition, 78(4):615-623.

Ragab, S. Mona (2013).Impact of betaine supplementation triticale diets varying in their metabolizable energy content on boiler performance during summer season. Egyptian. J. Nutr. and Feeds, 16(1):113129.

Ratriyanto, A.; R. Mosenthin; E. Bauer and M.E Klund (2009).Methbolic, osmoregulatory and nutrition functions of betaine in monogastric animals. Asian-Australas.J. Anim. Sci., 22:1461-1476.

Remus, J.C. (2002). Betaine may minimize effects of heat stress in broilers. Feedstuffs, 74:11-13.

Remus, J.C.; E.E. M.pierson and M.H Ruby (2004). The evaluation of betaine and enzymes in coccidian challenged broilers. XXII poultry congress,I stanbul, Turkey 8-13June.

Safaa H.M. (2013). Influnce of dietary enzymes prepared at ensiling (ZADO-R-) from hatch to 42 days of age on productivity, slaughter traits and blood constituents in broiler chickens .Int. J.of Poult. Sci., 12(9):529-537.

Saleh, F.; M. Tahir; A. Ohtsuka and K. Hayashi (2005). A mixture of pure cellulase, hemicellulase and pectinase improves broiler performance. Br. Poult. Sci., 46:602-606.

Elnagar, H.M. Sanaa (20120.Impact of enzyme mixture, probiotic or both on performance of broilers fed sorghum based diets. Egyption J. Nutrition and feeds, 15(1):123-132.

Seedor, J.G.; H.A.Quarruccio and D.D. Thompson (1991). The biophosphorate alendronate (MK-217) inhibits bone loss due to ovariectomy in rates.Journal of bone and Mineŕal Research, 6:339-2550. 
Wang, J.; R. Du; J. Qin; S. Wang; W. Wang; H. LI and Q. Pang (2003). Effect of yeast chromium and Lcarnitine on lipid metabolism of broiler chickens. Asian-Australasian Journal of Animal Sciences, 12:1809-1815.

Wang, Y.Z.; Z.R. Xu and G. Feng (2004). The effect of Betaine and DL-methionine on growth performance and carcass characteristics in meat ducks. Anim. Feed Sci. Technol., 116:151-159.

XU, Z.R.; M. Wang; Q. Mao and H.X. Zhan X.A.H.U.C.H. (2003). Effects of L-carnitine on growth performance, carcass composition and metabolism of lipids in male broilers. Poult.Sci., 82:408-413.

Yakout, H.M.; Mona Osman; A.E. Abo-Zeid and Kh. Amber (2004). The lysine requirement and ratio of total sulfur amino acids to lysine for growing Japanese quails fed adequate or inadequate lysine. Egypt. Poult. Sci., 24(11):497-507.

Yalcin, S.; B. Ozsoy; O. Cengiz and T. Bubbul (2008). Effects of dietary L-carnitine supplementation on growth performance and some biochemical parameters in Japanese quails (coturnix coturnix Japonica). R evue Méd.vét. 2008, 159:502-507.

Yu, B. and T.K. Chung (2004). Effects of multiple-enzyme mixtures on growth performance of broilers fed corn-soybean meal diets. J. Appl. Poult. Res., 13:178-182.

Zhan, X.A.; X. J.LI and Q. Zhao (2006). Effects of methionine and betaine supplement on growth performance, carcass composition and metabolism of lipids in male broiler. Br. Poult. Sci., 47:576580.

Zhang, Y.; Q. Ma; Baix; L. Zhao Wang; Q. JIC; L. Liu and H. Yin (2010). Effects of chietary acetyl-Lcarnitine on meat quality and lipid metabolism in Arbor Acres broilers. Asian-Australasian Journal of Animal Sciences, 12:1639-1644.

تقييم الاداء الانتاجى والاقتصادى لاستخدام بعض اضافات الاعلاف فى العلائق النباتيه لبدارى التسمين.

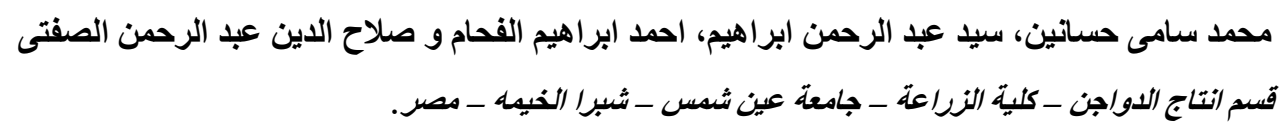

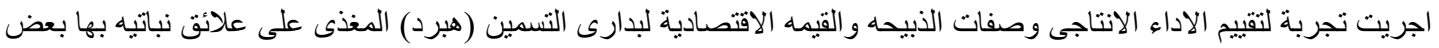

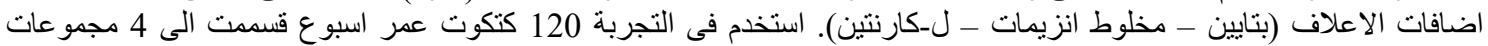

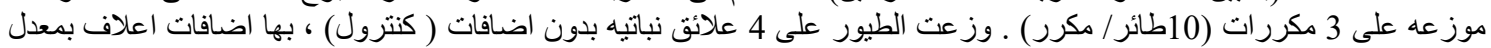

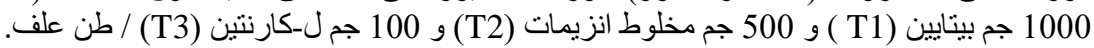

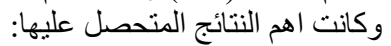

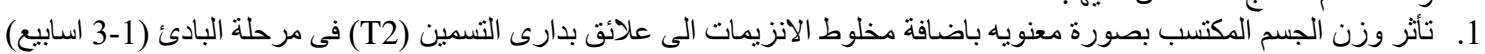
و النامى (4-5 اسبوع) بينما طول فترة التجربة (1-5 اسبوع) اظهرت جميع المعاملات الغذائيه (T1-3) تحسن غئن (T) فير معنوى بالمقارنه بمجمو عة الكنترول.

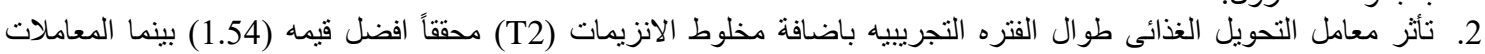

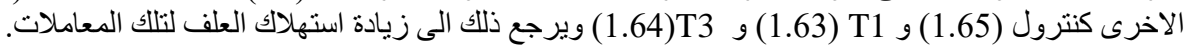

3.

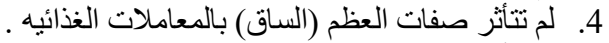

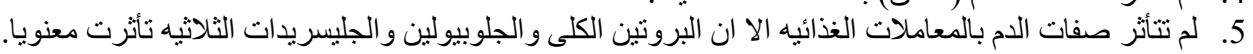

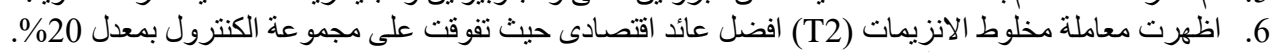

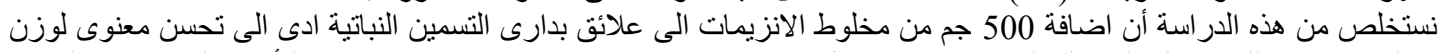

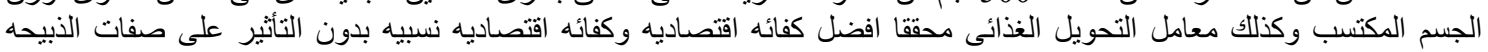

و القطعيات المختلفه. 
Table (1). Composition and calculated chemical analysis of the starter and grower experimental basal diets

\begin{tabular}{|c|c|c|}
\hline Ingredients $\%$ & Starter basal diet (1-3 weeks)* & Grower basal diet (4-5 weeks)* \\
\hline Yellow corn & 46.45 & 54.44 \\
\hline Soybean meal (44\%) & 36.20 & 30.15 \\
\hline Full fat soya & 9.00 & 9.00 \\
\hline Sunflower oil +soybean oil & 3.65 & 2.00 \\
\hline Mono calcium phosphate & 1.85 & 1.68 \\
\hline Limestone & 1.60 & 1.48 \\
\hline Salt (Na cl) & 0.40 & 0.40 \\
\hline DL. Methionine & 0.34 & 0.20 \\
\hline L.lysine $\mathrm{H} \mathrm{cl}$ & 0.08 & 0.22 \\
\hline Vit and Min premix $* *$ & 0.30 & 0.30 \\
\hline Choline chloride $50 \%$ & 0.13 & 0.13 \\
\hline Total & 100 & 100 \\
\hline \multicolumn{3}{|c|}{ Calculated chemical analysis $* * *$} \\
\hline Crude protein $\%$ & 23.12 & 21.13 \\
\hline $\mathrm{ME}(\mathrm{kcal} / \mathrm{kg})$ & 3071 & 3045 \\
\hline Calcium \% & 1.02 & 0.93 \\
\hline Available phosphorus $\%$ & 0.50 & 0.46 \\
\hline Lysine \% & 1.39 & 1.39 \\
\hline Methionine \% & 0.72 & 0.55 \\
\hline Methionine + cysteine $\%$ & 1.06 & 0.88 \\
\hline Cost / 1 ton (L.E.) & 3700 & 3600 \\
\hline \multicolumn{3}{|c|}{ 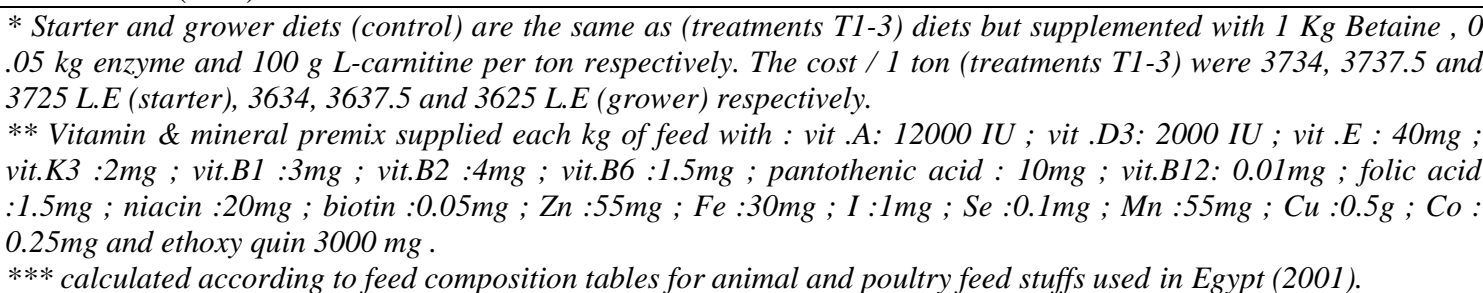 } \\
\hline
\end{tabular}

Table (2). Effect of dietary treatments on growth performance of broiler chicks.

\begin{tabular}{|c|c|c|c|c|c|}
\hline \multirow[b]{2}{*}{ Items } & \multicolumn{4}{|c|}{ Dietary treatments } & \multirow[t]{2}{*}{ Significant } \\
\hline & Control & $\mathrm{T} 1$ & $\mathrm{~T} 2$ & T3 & \\
\hline $\begin{array}{l}\text { Initial body weight }(\mathrm{g}) \\
1-3 \text { weeks of age }\end{array}$ & $125.5 \pm 0.87$ & $131.0 \pm 0.58$ & $122.5 \pm 0.29$ & $130.0 \pm 1.16$ & NS \\
\hline Body weight gain (g) & $680^{a} \pm 2.60$ & $688^{a} \pm 6.35$ & $634.5^{b} \pm 25.12$ & $714^{\mathrm{a}} \pm 5.2$ & $*$ \\
\hline Feed consumption $(\mathrm{g})$ & $985.5 \pm 15.88$ & $964 \pm 9.82$ & $949 \pm 34.06$ & $992 \pm 14.43$ & NS \\
\hline $\begin{array}{l}\text { Feed conversion } \\
\text { ( } g \text { feed / g gain ) } \\
4 \text { - } 5 \text { weeks of age }\end{array}$ & $1.45 \pm 0.02$ & $1.40 \pm 0.01$ & $1.50 \pm 0.01$ & $1.39 \pm 0.01$ & NS \\
\hline Body weight gain (g) & $1301 \pm 5.20^{\mathrm{b}}$ & $1318 \pm 62.93^{b}$ & $1400.5 \pm 58.02^{a}$ & $1331.0 \pm 25.98^{\mathrm{b}}$ & $*$ \\
\hline Feed consumption $(\mathrm{g})$ & $2268 \pm 6.93$ & $2290 \pm 52.54$ & $2173.5 \pm 66.68$ & $2343 \pm 17.32$ & NS \\
\hline $\begin{array}{l}\text { Feed conversion } \\
\text { ( } \mathrm{g} \text { feed / } \mathrm{g} \text { gain }) \\
1-5 \text { weeks of age }\end{array}$ & $1.69^{a b} \pm 0.06$ & $1.75^{\mathrm{ab}} \pm 0.04$ & $1.63^{b} \pm 0.13$ & $1.77^{\mathrm{a}} \pm 0.09$ & $*$ \\
\hline Body weight gain (g) & $1981.5 \pm 2.6$ & $2006 \pm 16.45$ & $2035 \pm 32.91$ & $2045 \pm 20.79$ & NS \\
\hline Feed consumption $(\mathrm{g})$ & $3253 \pm 22.81$ & $3254 \pm 62.35$ & $3122.5 \pm 100.75$ & $3335 \pm 31.75$ & NS \\
\hline$\%$ & 100 & 100 & 96 & 102 & \\
\hline $\begin{array}{l}\text { Feed conversion } \\
\text { ( } \mathrm{g} \text { feed / g gain })\end{array}$ & $1.65^{\mathrm{a}} \pm 0.02$ & $1.63^{\mathrm{ab}} \pm 0.03$ & $1.54^{\mathrm{b}} \pm 0.08$ & $1.64^{\mathrm{ab}} \pm 0.03$ & $*$ \\
\hline$\%$ & 100 & 98 & 93 & 99 & \\
\hline
\end{tabular}


Table (3). Effect of different experimental diets on carcass characteristics of broiler chicks at 5 weeks.

\begin{tabular}{|c|c|c|c|c|c|}
\hline \multirow[b]{2}{*}{ Items } & \multicolumn{4}{|c|}{ Dietary treatments } & \multirow[t]{2}{*}{ Significant } \\
\hline & Control & $\mathrm{T} 1$ & $\mathrm{~T} 2$ & T3 & \\
\hline $\begin{array}{l}\text { Pre-slaughter } \\
\text { weight }(\mathrm{g})\end{array}$ & $2182.00 \pm 128.04$ & $2025.67 \pm 88.88$ & $2102.00 \pm 114.72$ & $2225.00 \pm 7.77$ & NS \\
\hline Carcass weight (g) & $1626.33 \pm 121.84$ & $1444.00 \pm 91.36$ & $1527.00 \pm 67.00$ & $1659.67 \pm 18.84$ & NS \\
\hline Dressing, $\%$ & $74.57 \pm 1.13$ & $71.15 \pm 1.51$ & $72.69 \pm 0.98$ & $74.89 \pm 1.33$ & NS \\
\hline Liver, $\%$ & $2.12 \pm 0.06$ & $2.40 \pm 0.04$ & $1.90 \pm 0.23$ & $2.59 \pm 0.25$ & NS \\
\hline Gizzard, \% & $1.11 \pm 0.16^{\mathrm{b}}$ & $1.52 \pm 0.12^{\mathrm{a}}$ & $1.31 \pm 0.12^{\mathrm{ab}}$ & $1.35 \pm 0.23^{\mathrm{ab}}$ & $*$ \\
\hline Heart, \% & $0.60 \pm 0.03$ & $0.59 \pm 0.04$ & $0.59 \pm 0.08$ & $0.67 \pm 0.06$ & NS \\
\hline Giblets, \% & $\begin{array}{l}3.82 \pm 0.19^{b} \\
100\end{array}$ & $\begin{array}{l}4.52 \pm 0.08^{a} \\
118.3\end{array}$ & $\begin{array}{l}3.80 \pm 0.41^{b} \\
99.5\end{array}$ & $\begin{array}{l}4.61 \pm 0.46^{b} \\
120.7\end{array}$ & $*$ \\
\hline $\begin{array}{l}\text { Ready to cook, } \\
\%^{*}\end{array}$ & 78.39 & 75.67 & 76.49 & 79.5 & NS \\
\hline Abdominal fat $\%$ & $\begin{array}{l}1.59 \pm 0.10 \\
100\end{array}$ & $\begin{array}{l}1.70 \pm 0.6 \\
106.9\end{array}$ & $\begin{array}{l}1.69 \pm 0.35 \\
106.3\end{array}$ & $\begin{array}{l}2.15 \pm 0.18 \\
135.2\end{array}$ & NS \\
\hline
\end{tabular}

$*$ Ready to cook $=$ hot carcass weight + giblets weight

Table (4). Effect of different experimental diets on carcass parts (\%) of broiler chicks at 5 weeks.

\begin{tabular}{lccccc}
\hline \multirow{2}{*}{ Items } & \multicolumn{4}{c}{ Dietary treatments } & \multirow{2}{*}{ Significant } \\
\cline { 2 - 5 } & Control & T1 & T2 & T3 & \\
\hline Breast & $47.41 \pm 1.53$ & $47.80 \pm 0.85$ & $48.57 \pm 1.43$ & $47.41 \pm 1.53$ & NS \\
Thigh & $27.19 \pm 0.69$ & $27.25 \pm 0.59$ & $26.05 \pm 0.94$ & $27.19 \pm 0.69$ & NS \\
Drumstick & $13.59 \pm 1.02$ & $13.93 \pm 0.37$ & $14.67 \pm 0.29$ & $13.59 \pm 1.02$ & NS \\
Wing & $11.00 \pm 1.24$ & $11.03 \pm 0.18$ & $10.45 \pm 0.77$ & $11.00 \pm 1.24$ & NS \\
Breast muscle & $24.45 \pm 2.21$ & $24.59 \pm 0.99$ & $25.62 \pm 0.45$ & $23.92 \pm 1.32$ & NS \\
Pectorals major & $19.25 \pm 1.36$ & $19.34 \pm 0.75$ & $21.18 \pm 0.73$ & $20.12 \pm 1.10$ & NS \\
Pectorals minor & $5.20 \pm 0.89$ & $5.26 \pm 0.28$ & $4.44 \pm 0.30$ & $3.81 \pm 0.36$ & NS \\
\hline
\end{tabular}

Table (5). Effect of different experimental diets on some bone measurements.

\begin{tabular}{lccccc}
\hline Items & \multicolumn{4}{c}{ Dietary treatment } & \multirow{2}{*}{ Significant } \\
\cline { 2 - 5 } & Control & $\mathrm{T} 1$ & $\mathrm{~T} 2$ & $\mathrm{~T} 3$ & \\
\hline Wet tibia weight $(\mathrm{g})$ & 11.33 & 10.72 & 12.37 & 11.65 & $\mathrm{NS}$ \\
$\%$ & $0.54 \pm 0.06$ & $0.50 \pm 0.03$ & $0.57 \pm 0.03$ & $0.54 \pm 0.04$ & $\mathrm{NS}$ \\
Tibia length (mm) & $8.67 \pm 0.24$ & $8.93 \pm 0.06$ & $8.47 \pm 0.17$ & $8.90 \pm 0.26$ & $\mathrm{NS}$ \\
Tibia width (mm) & $0.65 \pm 0.02$ & $0.58 \pm 0.04$ & $0.63 \pm 0.03$ & $0.63 \pm 0.03$ & $\mathrm{NS}$ \\
Tibia Seedor Indx (SI) & $0.65 \pm 0.03$ & $0.62 \pm .03$ & $0.69 \pm 0.03$ & $0.65 \pm 0.02$ & NS \\
\hline
\end{tabular}


Table (6). Effect of experimental treatments on some blood plasma components of growing chicks.

\begin{tabular}{|c|c|c|c|c|c|}
\hline \multirow{2}{*}{ Items } & \multicolumn{4}{|c|}{ Treatments } & \multirow[t]{2}{*}{ Significant } \\
\hline & Control & $\mathrm{T} 1$ & $\mathrm{~T} 2$ & $\mathrm{~T} 3$ & \\
\hline $\begin{array}{l}\text { Total protein }(\mathrm{g} / \\
\mathrm{dl})\end{array}$ & $3.36^{\mathrm{a}} \pm 0.29$ & $1.77^{b} \pm 0.12$ & $2.15^{\mathrm{b}} \pm 0.35$ & $3.46^{\mathrm{a}} \pm 0.33$ & $*$ \\
\hline Albumin (g/ dl) & $1.54 \pm 0.11$ & $1.30 \pm 0.17$ & $1.40 \pm 0.32$ & $1.34 \pm 0.19$ & NS \\
\hline Globulin (g/ dl) & $1.82^{\mathrm{a}} \pm 0.34$ & $0.47^{b} \pm 0.15$ & $0.75^{\mathrm{b}} \pm 0.07$ & $2.12^{\mathrm{a}} \pm 0.15$ & $*$ \\
\hline $\mathrm{A} / \mathrm{G}$ ratio & $0.96^{b} \pm 0.21$ & $4.23^{\mathrm{a}} \pm 2.36$ & $1.86^{\mathrm{ab}} \pm 0.42$ & $0.63^{b} \pm 0.05$ & $*$ \\
\hline Triglyceride, g/ dl & $78.24^{\mathrm{ab}} \pm 5.18$ & $63.57^{\mathrm{ab}} \pm 10.28$ & $59.12^{b} \pm 12.07$ & $112.41^{\mathrm{a}} \pm 12.04$ & $*$ \\
\hline $\begin{array}{l}\text { Total cholesterol } \\
(\mathrm{g} / \mathrm{dl})\end{array}$ & $88.28 \pm 24.40$ & $69.99 \pm 8.11$ & $113.94 \pm 28.62$ & $123.60 \pm 21.74$ & NS \\
\hline $\begin{array}{l}\text { Low density } \\
\text { lipoprotein }(\mathrm{g} / \mathrm{dl})\end{array}$ & $67.06 \pm 24.31$ & $56.76 \pm 9.11$ & $85.72 \pm 17.38$ & $98.53 \pm 17.55$ & NS \\
\hline $\begin{array}{l}\text { High density } \\
\text { lipoprotein }(\mathrm{g} / \mathrm{dl})\end{array}$ & $21.22 \pm 6.49$ & $14.22 \pm 4.05$ & $28.22 \pm 11.24$ & $25.07 \pm 4.34$ & NS \\
\hline
\end{tabular}

Table (7). Effect of feeding different dietary treatments on economic evaluation.

\begin{tabular}{lcccc}
\hline \multirow{2}{*}{ Items } & \multicolumn{3}{c}{ Treatments } \\
\cline { 2 - 5 } & Control & T1 & T2 & T3 \\
\hline Live body weight (kg) & 2.107 & 2.137 & 2.157 & 2.175 \\
Price/ kg body weight (LE) & 12 & 12 & 12 & 12 \\
Total revenue/ chick (LE) & 25.284 & 25.644 & 25.89 & 26.10 \\
Total feed intake/ chick(kg) & 3.253 & 3.254 & 3.122 & 3.335 \\
Total feed cost/ chick(LE) & 11.811 & 11.921 & 11.453 & 12.189 \\
Fixed cost/ chick (LE) & 8 & 8 & 8 & 8 \\
Total cost/ chick (LE) & 19.811 & 19.921 & 19.453 & 20.189 \\
Net revenue (LE) & 5.473 & 5.723 & 6.437 & 5.911 \\
Economic efficiency (EE) & 27.6 & 28.7 & 33.1 & 29.3 \\
Relative (EE)\% & 100 & 104 & 120 & 106 \\
\hline
\end{tabular}

